\title{
Odrednice pomaganja žrtvi u situacijama vršnjačkog nasilja
}

\author{
Tamara Martinac Dorčić, Sanja Smojver-Ažić, \\ Barbara Rončević Zubković i Svjetlana Kolić-Vehovec
}

Sveučilište u Rijeci, Filozofski fakultet, Odsjek za psihologiju, Rijeka, Hrvatska

\begin{abstract}
Sažetak
Iako promatrači vršnjačkog nasilja aktivno ne sudjeluju u vršnjačkom nasilju, njihove reakcije mogu odigrati važnu ulogu u zaštiti žrtve. Cilj je rada ispitati u kojoj mjeri socijalne vještine, prepoznavanje primjerenih reakcija u situacijama vršnjačkog nasilja te samodjelotvornost i subjektivne norme vezane uz zaštitu žrtve mogu predvidjeti pomaganje žrtvi. U istraživanju su sudjelovali učenici od 12 do 14 godina $(M=12.69 ; S D=0.72)$ iz deset europskih škola (Španjolske, Malte, Velike Britanije i Irske). Od početnog uzorka 359 učenika analizirani su odgovori 226 učenika (54.9\% djevojčica) koji u situacijama vršnjačkog nasilja nisu bili žrtve i/ili nasilnici te su izjavili da u situacijama vršnjačkog nasilja nastoje pomoći žrtvi $(70.8 \%)$ ili da u situacijama vršnjačkog nasilja ne čine ništa, ali smatraju da bi trebali pomoći (29.2\%). Sudionici su ispunjavali online upitnik u školi, uz nadzor nastavnika. Upitnik se sastojao od niza skala, konstruiranih ili prilagođenih za potrebe ovog istraživanja kojima smo ispitali ciljane varijable: Upitnik nasilnik/žrtva, Skala empatije, Skala percipiranih socijalnih vještina, Skala samodjelotvornosti u zaštiti žrtve, Skala subjektivnih normi vezanih uz zaštitu žrtve te Upitnik primjerenosti reakcija u situaciji vršnjačkog nasilja. Doprinos promatranih varijabli u objašnjenju ponašanja pomaganja žrtvi ispitan je primjenom hijerarhijske logističke regresijske analize. Rezultati pokazuju da ispitane varijable u posljednjem koraku objašnjavaju između $18 \%$ i $25 \%$ varijance pomaganja žrtvi. Prepoznavanje primjerenosti reakcija u situacijama vršnjačkog nasilja (primjerenost asertivnih reakcija i neprimjerenost agresivnih i pasivnih reakcija) te samodjelotvornost u zaštiti žrtve značajni su pozitivni prediktori pomagačkog ponašanja. Dobiveni rezultati upućuju na važnost prepoznavanja i osvještavanja primjerenih reakcija promatrača u kontekstu vršnjačkog nasilja te jačanja samodjelotvornosti s ciljem povećanja vjerojatnosti pomaganja žrtvi.
\end{abstract}

Ključne riječi: vršnjačko nasilje, pomaganje žrtvi, empatija, socijalne vještine, samodjelotvornost

Tamara Martinac Dorčić, Odsjek za psihologiju, Filozofski fakultet, Sveučilište u Rijeci, Sveučilišna avenija 4, Rijeka, Hrvatska. E-pošta: tamaram@ffri.hr

Istraživanje je provedeno u sklopu projekta eConfidence, financiranog iz programa Europske unije za istraživanje i inovacije "Obzor 2020", ugovor o subvenciji 732420.

Zahvaljujemo svim partnerima na projektu na suradnji u provođenju istraživanja. 


\section{Uvod}

Vršnjačko nasilje prepoznat je društveni problem među djecom i adolescentima širom svijeta. Označava se različitim terminima, ali ga treba razlikovati od vršnjačkog zlostavljanja. Prema Olweusu (1993) vršnjačko zlostavljanje definirano je trima kriterijima: namjernom agresijom, ponavljanjem i nerazmjerom moći između počinitelja nasilja i žrtve. Vršnjačko nasilje pak ne mora nužno imati sve navedene karakteristike te predstavlja kategoriju koja je nadređena vršnjačkom zlostavljanju (Rajhvan Bulat i Ajduković, 2012). Vršnjačko nasilje uključuje znatan dio školske populacije, a konkretne brojke variraju ovisno o istraživanju i samim definicijama vršnjačkog nasilja. Primjerice, Wolke i Lereya (2015) navode da jedno od troje djece izvještava da su barem jednom u svom životu bila žrtve nasilja, dok je između 10 i 14\% djece žrtava kroničnoga vršnjačkog nasilja, koje traje više od 6 mjeseci. Velki i Kuterovac Jagodić (2014) u svom preglednom radu navode da ga prema istraživanjima vrši 3 do $27 \%$, a trpi oko 9 do $32 \%$ školske djece. U istraživanjima u Hrvatskoj dobiveni su slični podaci o učestalosti (Buljan Flander, Durman Marijanović i Ćorić Špoljar, 2007; Reić Ercegovac, 2016; Sušac, Ajduković i Rimac, 2016). Učestalost vršnjačkog nasilja nije linearno povezana s dobi učenika: tijekom osnovnoškolske dobi vršnjačko nasilje raste i najučestalije je u završnim razredima osnovne škole te nižim razredima srednje škole, nakon čega slijedi pad (Olweus, 1998; Velki i Kuterovac-Jagodić, 2014). Kada se analiziraju spolne razlike, dosadašnja istraživanja pokazuju da se muški spol češće povezuje s tjelesnim nasiljem dok se kod relacijskog nasilja ne dobivaju konzistentne razlike (Reić Ercegovac, 2016; Velki i Kuterovac-Jagodić, 2014). Vršnjačko nasilje često je povezano s psihosocijalnom prilagodbom - većom zastupljenošću internaliziranih problema kao što su depresivni, anksiozni i psihosomatski simptomi (Reijntjes i sur., 2010; Zwierzysnka, Wolke i Lereya, 2013) i eksternaliziranih problema poput agresivnosti (Reijntjes i sur., 2011) te slabijim školskim uspjehom (Glew, Fan, Katon, Rivara i Kernic, 2005; Reić Ercegovac, 2016).

U kontekstu vršnjačkog nasilja mogu se razlikovati različite uloge djece: uloge žrtve, počinitelja nasilja ili istovremene žrtve i počinitelji nasilja (Sušac i sur., 2016). Međutim, većina djece nije uključena u vršnjačko nasilje i njih nazivamo promatračima (engl. bystander). Iako djeca koja nisu uključena u vršnjačko nasilje ne sudjeluju aktivno u situacijama vršnjačkog nasilja, njihove reakcije mogu biti ključne za zaštitu žrtve (Coloroso, 2005) jer mogu potkrijepiti ili kazniti počinitelja nasilja i tako podržati ili prekinuti krug vršnjačkog nasilja. Promatrači mogu različito reagirati: promatrati nasilje i ne pomoći žrtvi, uživati u promatranju nasilja i poticati počinitelja, pomagati počinitelju tako što će ga upozoriti ako tko dolazi, no, isto tako mogu suosjećati sa žrtvom i ne odobravati nasilje (Gini, Pozoli, Borghi i Franzoni, 2008). Prvi su uloge promatrača analizirali Salmivalli, Lagerspetz, Björkqvist, Österman i Kaukiainen (1996). Oni razlikuju pomagače i potkrepljivače počinitelja nasilja, pomagače žrtvi i one koji ne znaju za nasilje ili ga ignoriraju, odnosno aktivne pomoćnike, pasivne pomoćnike, branitelje i promatrače (Alajbeg, Dragoslavić i 
Vrljičak Davidović, 2018). Padget i Notar (2013) dodatno razlikuju promatrače koji iako ne pomažu, osjećaju krivnju te nezabrinute pomagače, koji ne pomažu i ne misle da bi trebali.

Pomaganje žrtvama u situacijama vršnjačkog nasilja nije toliko rašireno koliko bi se moglo očekivati s obzirom na raširenost negativnih stavova prema vršnjačkom nasilju (Boulton, Bucci i Hawker, 1999; Rigby i Johnson, 2006; Salmivalli i Voeten, 2004), a postoci variraju ovisno o načinu prikupljanja podataka o pomagačkom ponašanju (vršnjačka procjena ili samoprocjena) i o dobi ispitanika (Rigby i Johnson, 2006). Tako primjerice, Salmivalli i Voeten (2004) navode da većina promatrača u preadolescentnoj $\mathrm{i}$ adolescentnoj dobi ne čini ništa kako bi pomogla žrtvi u situacijama vršnjačkog nasilja, odnosno samo njih $20 \%$ pomaže žrtvi, 20-30\% samo promatra, a 20-30\% učenika čak potkrepljuje počinitelja. Oh i Hazler (2009) navode da većina promatrača (59\%) odabire ostati neuključena u situacije vršnjačkog nasilja, a $31 \%$ sudionika brani žrtvu. Stoga se dio istraživača usmjerio na utvrđivanje osobnih i situacijskih odrednica povezanih $\mathrm{s}$ različitim ponašanjima promatrača $\mathrm{u}$ epizodama vršnjačkog nasilja, a sličnosti i razlike među skupinama promatrača (pomagača i pasivnih promatrača) detektirane su kako na individualnoj, tako i na socijalnoj/kontekstualnoj razini. U ovom ćemo se radu usmjeriti upravo na faktore na osobnoj razini: empatiju i socijalne vještine, znanje o poželjnom ponašanju, subjektivne norme i samodjelotvornost. Jedno je od polazišta ovog istraživanja teorija planiranog ponašanja (Ajzen, 1991), u kojoj namjera ponašanja, odnosno motivacija pojedinca da se ponaša na odgovarajući način osim o stavovima ovisi i o njegovim subjektivnim normama te percepciji samodjelotvornosti.

\section{Empatija}

Empatija je često promatran čimbenik u kontekstu vršnjačkog nasilja. Odnosi se na sposobnost razumijevanja i doživljavanja osjećaja druge osobe (Davis, 1983; Nesdale, Griffiths, Durkin i Maass, 2005). Najčešće se razmatra kao višedimenzionalni konstrukt te se razlikuje kognitivna i afektivna komponenta empatije. Kognitivna se empatija odnosi na sposobnost razumijevanja emocionalnog stanja druge osobe i prihvaćanja njezinih emocija, dok je za afektivnu komponentu karakteristična sposobnost dijeljenja emocionalnog stanja drugog i doživljaj emocije koji je usklađen sa situacijom u kojoj se nalazi ta osoba (Davis, 1983). U istraživanjima o povezanosti između empatije i uključenosti u vršnjačko nasilje analizirane su različite komponente empatije (kognitivna, afektivna), vrste sudjelovanja u nasilničkom ponašanju (npr. nasilje, viktimizacija, pomaganje) i oblici vršnjačkog nasilja (npr. fizičko, verbalno, relacijsko, internetsko). U istraživanjima se češće analizira uloga empatije u reakcijama počinitelja nasilja, dok je manje istražen njezin doprinos u objašnjenju ponašanja promatrača (Van Noorden, Haselager, Cillessen i Bukowski, 2015). 
Istraživanja odnosa komponenti empatije $s$ vršnjačkim nasiljem daju kontradiktorne rezultate. Dok su za kognitivnu empatiju pronađene i pozitivne i negativne povezanosti s ulogom promatrača, za afektivnu se komponentu nalazi negativna ili nulta korelacija (Van Noorden i sur., 2015). Tako Gini, Albiero, Benelli i Altoe (2008) nalaze nisku pozitivnu povezanost kognitivne empatije i ne reagiranja nakon kontrole spola, a Belacchi i Farina (2012) navode negativnu povezanost kognitivne empatije i nereagiranja. Lovett i Sheffield (2007) zaključili su da negativna povezanost između emocionalne empatije i nasilja postoji samo kod starije djece i adolescenata, a ne kod mlađe djece. Slično nalazu Millera i Eisenberga (1988) ova je negativna povezanost bila najsnažnija kada je empatija procijenjena pomoću upitnika. Čini se da povezanost empatije s vršnjačkim nasiljem ovisi ne samo o vrsti empatije i ulozi koju dijete ima u kontekstu vršnjačkog nasilja nego i o brojnim moderatorima kao što su spol, dob i operacionalizacija konstrukta empatije.

Djeca uključena u nasilje nisu nužno nesposobna znati što drugi osjećaju, iako se čini da imaju oslabljenu sposobnost da osjete ono što drugi osjećaju (Bryant, 1982). Dakle, iako nasilnici razumiju što drugi osjećaju, ne znači da doživljavaju ono što drugi osjećaju. Ovi su rezultati u skladu s onima drugih autora (Jolliffe i Farrington, 2006; Sutton, Smith i Swettenham, 1999) koji su izjavili da je doživljavanje osjećaja drugih - a ne samo razumijevanje njihovih osjećaja - ono što utječe na sklonost djece da se suzdrže od nasilja. Moguće je da nasilnici mogu imati bolje vještine kognitivne empatije i bolje zaključiti o tuđim emocijama od samih žrtava ili promatrača.

Kada se analizira povezanost kognitivne i afektivne empatije s ponašanjem obrane žrtve u situacijama vršnjačkog nasilja, također se dobivaju nekonzistentni zaključci o ulozi empatije. Tako primjerice Espelage, Green i Polanin (2012) nalaze kako se namjera pomaganja žrtvi može predvidjeti samo kognitivnom empatijom za dječake, a više istraživanja potvrđuje ulogu afektivne empatije (Belacchi i Farina, 2012; Gini, Albiero, Benelli i Altoè, 2007), dok Pöyhönen, Juvonen i Salmivalli (2010) nisu našli povezanost ni s jednom od komponenti. Što se tiče odnosa afektivne empatije i pomagačkog ponašanja promatrača, potvrđuje se povezanost afektivne empatije i ovog oblika ponašanja, premda su ove veze nerijetko ovisne o spolu i dobi djece i adolescenata (Belacchi i Farina, 2012; Caravita, Di Blasio i Salmivalli, 2009; Van Noorden i sur., 2015).

Neke novije studije upućuju na to da se empatija, a posebno empatički stres, može razlikovati od empatijske skrbi ili suosjećanja (Bloom, 2017). Singer i Klimecki (2014) tvrde da se empatija obično odnosi na našu opću sposobnost zaključivanja o pozitivnim i negativnim emocionalnim stanjima drugih, za razliku od empatičkog stresa, koji se odnosi na snažan emocionalni odgovor na patnju drugih, praćen željom da se povuče iz situacije kako bi se zaštitili od prekomjernih negativnih osjećaja. Suosjećanje, s druge strane, upućuje na osjećaj zabrinutosti za tuđu patnju, umjesto dijeljenje patnje s drugom osobom. Razlika između suosjećanja i empatije uočava se i na razini neuroloških reakcija (Bloom, 2017). Suosjećanje 
karakteriziraju osjećaji topline i brige za osobu koja pati, uz motivaciju za pomoć. U studiji koja istražuje učinke empatije i suosjećanja na prosocijalno djelovanje, Jordan, Amir i Bloom (2016) nalaze kako suosjećanje, ali ne i empatija, predviđa prosocijalne akcije, zbog čega suosjećanje može biti posebno važan ishod u preventivnim aktivnostima usmjerenim na prevenciju i zaštitu žrtava. Iako važna, čini se da empatija, bez obzira na način na koji je konceptualizirana, nije dovoljna za objašnjenje ponašanja pomaganja žrtvi te da pomaganje žrtvi ovisi i o drugim faktorima.

\section{Socijalne vještine}

Socijalne vještine promatrača također mogu određivati njihovo reagiranje $u$ situacijama vršnjačkog nasilja. One uključuju niz verbalnih i neverbalnih odgovora koji utječu na percepciju i odgovor drugih ljudi tijekom socijalnih interakcija (Spence, 2003). Da bi uspješno djelovali u društvu, pojedinci trebaju moći integrirati različite vještine u odgovarajuće strategije za rješavanje određenih socijalnih zadataka. Postoji velik broj socijalnih zadataka s kojima se mladi trebaju nositi, kao što su primjerice traženje i pružanje pomoći, odbijanje zahtjeva, traženje informacija i sl. Neki autori (Perren, Forrester-Knauss i Alsaker, 2012) razlikuju socijalne vještine usmjerene na sebe (vještine vođene osobnim interesima ili dobrobiti, npr. asertivnost $i$ vještine vođenja) i socijalne vještine usmjerene na druge (vještine vođene interesima $\mathrm{i}$ dobrobiti drugih $\mathrm{u}$ socijalnoj interakciji, npr. pomaganje, preuzimanje odgovornosti za druge, prosocijalno i kooperativno ponašanje). Socijalne vještine važan su dio razvoja, a deficiti na ovom području imaju dugoročne učinke na dijete (Matson i sur., 2010). Pomanjkanje socijalnih vještina može biti razlogom zašto djeca postaju žrtve vršnjačkog nasilja, jer se, primjerice, ne znaju obraniti od agresivnog napada (Perren i sur., 2012). Što se tiče počinitelja nasilja, još je uvijek otvoreno pitanje imaju li oni nedostatak socijalnih vještina (npr. Sutton i sur., 1999) ili je u osnovni njihova ponašanja deficit u moralnom razvoju (npr. Hymel, Schonert-Reichl, Bonanno, Vaillancourt i Henderson, 2010). Tako Perren i suradnici (2012) i Perren i Alsaker (2006) navode kako nasilnici imaju visoke socijalne vještine usmjerene na sebe, ali pokazuju niže razine socijalnih vještina usmjerenih na druge. Kod pomagača žrtvama nasilja karakteristične su socijalne vještine usmjerene na druge, zbog čega djeluju prosocijalno.

\section{Znanje o prihvatljivim ponašanjima}

Pomaganje žrtvama vršnjačkog nasilja ponašanje je na koje se djeca rjeđe odlučuju i to zbog straha da i sami ne postanu žrtve počinitelja nasilja, odnosno straha od osvete, ali i nerazumijevanja dinamike vršnjačkog nasilja i neznanja o tome što treba učiniti (Vannini i sur., 2011). Važnost znanja o prikladnim reakcijama u situaciji vršnjačkog nasilja istaknuta je već u modelu 5-stadija (Latane i Darley, 1969). Prema ovom modelu za intervenciju i pomaganje žrtvi potrebno je: 1. uočiti 
da se nešto događa, 2. interpretirati događaj kao važan i štetan, 3. preuzeti odgovornost za intervenciju, 4. znati što napraviti i 5. odlučiti se za pomaganje. Više se istraživačkog interesa usmjeravalo na prva tri koraka (Schroeder, Penner, Dovidio i Piliavin, 1995). Istraživanja su se više bavila time hoće li ili neće ljudi nešto učiniti, a ne time što će činiti. Naime, važno je ne samo da se osobe odluče na pomaganje već i da znaju što treba napraviti kako bi određena intervencija bila efikasna neadekvatno pomaganje može biti štetno kako za žrtvu, tako i za pomagača. Pomagači su osobe koje posjeduje više resursa (znanje, informacije ili vještine) od žrtve zbog čega su u poziciji da mogu reagirati (Van Leeuwen i Täuber, 2011).

\section{Samodjelotvornost i subjektivne norme}

Prema teoriji planiranog ponašanja (Ajzen, 1991, 2002) namjera ponašanja i samo ponašanje ovisno je i o percepciji samodjelotvornosti i subjektivnim normama. Samodjelotvornost je važan motivacijski konstrukt i unutar socijalno kognitivnog pristupa (Bandura, 1997, 2001). Samodjelotvornost podrazumijeva osobno uvjerenje pojedinca da može izvesti određeno ponašanje samo ako to želi i zbog toga uvjerenja spremnost za izvođenje određenog ponašanja (Ajzen, 1991, 2002). Iskustva u interakciji s vršnjacima mogu utjecati na procjenu socijalne samodjelotvornosti. Djeca koja imaju veću socijalnu samodjelotvornost spremnija su pomoći žrtvi, dok oni niske socijalne samodjelotvornosti ne vjeruju da su sposobni obraniti žrtvu i ostaju samo promatrači (Gini i sur., 2008; Pöyhönen i sur., 2012; Thonberg i Jungert, 2013).

Subjektivna norma definira se kao percipirani socijalni pritisak da se izvede odnosno ne izvede određeno ponašanje (Ajzen, 1991; Heirman i Walrave, 2012). Što više pojedinac percipira da važni drugi misle kako se treba ponašati na određeni način, to će pojedinac biti više motiviran da se prikloni pritisku od strane drugih. Ulogu značajnih drugih najčešće igraju roditelji, prijatelji i nastavnici. Subjektivne norme ispitivane su i u kontekstu vršnjačkog nasilja, a rezultati pokazuju da su vjerovanje kako roditelji i prijatelji očekuju od pojedinca da pomognu žrtvi značajni prediktori izražene namjere da pomognu (Pozzoli i Gini, 2013; Rigby i Johnson, 2006).

Razumijevanje čimbenika koji imaju efekte na različita ponašanja promatrača važno je jer daje smjernice za planiranje intervencija usmjerenih na smanjivanje vršnjačkog nasilja. Usmjerenost intervencija upravo na promatrače višestruko je opravdana (Salmivall, Voeten i Poskiparta, 2011). Naime, ponašanje promatrača lakše je mijenjati nego ponašanje počinitelja nasilja, a mijenjanjem ponašanja promatrača može se smanjiti potkrepljivanje nasilnog ponašanja, čime se i ono smanjuje.

S obzirom na to da je u kontekstu istraživanja vršnjačkog nasilja veća usmjerenost na žrtve i počinitelje (Yun i Graham, 2018), ovaj se rad usmjerio upravo na pomagače kao važnu kariku u prevenciji vršnjačkog nasilja i to na ispitivanje 
čimbenika vezanih uz pomagačko ponašanje. Pri tome smo pažnju usmjerili na razmatranje doprinosa onih čimbenika koji su podložni intervencijama i to u razdoblju rane adolescencije, kada odnosi s vršnjacima postaju važniji. Stoga je cilj ovog rada ispitati u kojoj mjeri socijalne vještine, prepoznavanje primjerenih reakcija u situacijama vršnjačkog nasilja te samodjelotvornost i subjektivne norme vezane uz zaštitu žrtve mogu predvidjeti ponašanje pomaganja žrtvi u razdoblju rane adolescencije. Očekuje se da će bolje socijalne vještine, bolje znanje o primjerenosti reakcija u situacijama vršnjačkog nasilja i samodjelotvornost te postojanje subjektivnih normi vezanih uz zaštitu žrtve biti povezane s pomagačkim ponašanjem.

\section{Metoda}

\section{Sudionici}

U istraživanju su sudjelovali učenici od 12 do 14 godina $(M=12.69 ; S D=0.72)$ iz deset europskih škola (pet škola u Španjolskoj, tri škole na Malti, jedna u Velikoj Britaniji i jedna u Irskoj). Istraživanje je provedeno u okviru projekta eConfidence (Confidence in behaviour changes through serious games - H2020) kao inicijalno istraživanje prije primjene ozbiljne igre $s$ ciljem promjene ponašanja promatrača $u$ smjeru pomaganja. Školama koje su se prijavile i bile odabrane za sudjelovanje u projektu poslane su upute za odabir 36 učenika metodom slučajnih brojeva. Od 359 učenika koji su u potpunosti ispunili online upitnike primijenjene za ispitivanje opažanih varijabli u daljnju su analizu uzeti odgovori 286 učenika $(79.7 \%$ početnog uzorka) koji su izjavili da u situacijama vršnjačkog nasilja nisu ni žrtve ni nasilnici niti provokativne žrtve (istovremeno i žrtve i nasilnici). Unutar skupine učenika neuključenih u vršnjačko nasilje njih $19 \%$ izjavilo je da nisu uočili vršnjačko nasilje, $1.7 \%$ samo promatra, $23 \%$ njih u situacijama vršnjačkog nasilja ne čini ništa, ali smatraju da bi trebali pomoći žrtvi, dok $56 \%$ izvještava da u situacijama vršnjačkog nasilja nastoje pomoći žrtvi. Za potrebe ovog istraživanja nisu uzeti u obzir odgovori onih koji nisu uočili vršnjačko nasilje ili samo promatraju tako da konačni uzorak na kojem su provedene analize čini 226 učenika (55\% učenica).

\section{Mjerni instrumenti}

U ispitivanju su korištena tri opća pitanja iz revidiranog Upitnika nasilnik/žrtva (Olweus, 1996). Pitanja se odnose na učestalost doživljavanja vršnjačkog nasilja od strane drugih u posljednjih nekoliko mjeseci (doživljeno nasilje), učestalost iskazivanja nasilnog ponašanja prema drugim učenicima u posljednjih nekoliko mjeseci (počinjeno nasilje) te uobičajene reakcije u situaciji promatranja vršnjačkog nasilja. Na pitanja o učestalosti doživljenog i počinjenog nasilja sudionici su davali procjene za pet različitih ponašanja vršnjačkog nasilja na skali od 1 (uopće ne) do 5 (nekoliko puta tjedno) pri čemu se raspon odgovora mogao kretati od 5 do 25 . Pri 
tome veći broj označava veću učestalost doživljenoga ili počinjenoga vršnjačkog nasilja. Sudionici koji su na pitanja o doživljenom odnosno počinjenom nasilju postizali više od 10 kategorizirani su kao žrtve odnosno počinitelji nasilja. Pouzdanost je skale doživljenog nasilja .77 , a počinjenog nasilja .85 . Na pitanje o uobičajenim reakcijama u situacijama promatranja vršnjačkog nasilja sudionici su odgovarali odabirom jednog od šest ponuđenih odgovora (nikad nisam primijetio da je neki od mojih vršnjaka doživio vršnjačko nasilje; uključujem se u nasilje; ne činim ništa, ali mislim da je u redu; samo promatram što se događa; ne činim ništa, ali mislim da bih trebao pomoći učeniku; pokušavam pomoći učeniku koji je žrtva nasilja).

$\mathrm{Za}$ ispitivanje empatije koristili smo šest čestica iz Indeksa empatije za djecu $i$ adolescente (engl. Bryant' Empathy Index for Children and Adolescents, Bryant, 1982), koja se u originalu sastoji od 22 čestice. Odabrane čestice odnose se na reagiranje na tugu druge osobe. Učenici su za svaku česticu procjenjivali stupanj slaganja s tvrdnjama (npr. Kada vidim da neki dječak plače i meni se plače; Tužan sam kada vidim dječaka koji ne može naći nikoga s kim bi se igrao) na Likertovoj skali od pet stupnjeva (od 1 - uopće se ne slažem do 5 - u potpunosti se slažem). Raspon je rezultata između 6 i 30, pri čemu se viši rezultat odnosi na veći stupanj afektivne empatije. Pouzdanost je skale na ovom uzorku 79.

Korišteno je osam tvrdnji iz supskale Prikladnih socijalnih vještina iz Matsonove evaluacije socijalnih vještina mladih (MESSY, Matson, Rotatori i Helsel, 1983). Učenici su procjenjivali stupanj slaganja s tvrdnjama (npr. Pomažem prijatelju koji je povrijeđen; Pitam ako mogu biti od pomoći) na Likertovoj skali od pet stupnjeva (od 1 - uopće se ne slažem do 5 - u potpunosti se slažem). Mogući je raspon rezultata između 8 i 40, pri čemu viši rezultat upućuje na bolje razvijene socijalne vještine. Pouzdanost je ove supskale .82 .

Za potrebe su ovog rada konstruirane tri tvrdnje koje mjere samodjelotvornost u zaštiti žrtve: Uvjeren sam da mogu zaštiti žrtvu; Lako mogu zaštititi žrtvu ako to želim; Meni je lako zaštititi žrtvu vršnjačkog nasilja. Sudionici su procjenjivali stupanj slaganja s navedenim tvrdnjama na skali Likertova tipa od pet stupnjeva (od 1 - uopće se ne slažem do 5 - u potpunosti se slažem). Mogući je raspon rezultata između 3 i 15, a viši rezultat upućuje na veću procjenu samodjelotvornosti u zaštiti žrtve. Pouzdanost je skale na cjelokupnom uzorku .79.

Za potrebe je ovog istraživanja konstruirana Skala subjektivnih normi vezanih uz zaštitu žrtve vršnjačkog nasilja, koja se sastoji od tri tvrdnje: Umojoj školi učenici štite žrtve vršnjačkog nasilja., Većina meni važnih ljudi misli da je dobro zaštititi žrtvu vršnjačkog nasilja., Osjećam da moji prijatelji očekuju od mene da zaštitim $\check{z ̌ r t v u ~ v r s ̌ n j a c ̌ k o g ~ n a s i l j a . ~ S u b j e k t i v n e ~ n o r m e ~ p r o c j e n j i v a n e ~ s u ~ n a ~ L i k e r t o v o j ~ s k a l i ~ o d ~}$ pet stupnjeva (od 1 -uopće se ne slažem do 5 - u potpunosti se slažem). Mogući je raspon od 3 do 15 , a viši rezultat upućuje na vjerovanje da je pomaganje žrtvi očekivano i poželjno ponašanje. Pouzdanost je skale na uzorku ovog istraživanja .63. 
Upitnik primjerenosti reakcija u situaciji vršnjačkog nasilja sastoji se od vinjeta koje su formulirane po uzoru na istraživanje autora Costleya, Sueng-Locka i Ji-Eun Hana (2013). Učenici su za svaku vinjetu (od kojih je šest opisivalo situacije vršnjačkog nasilja, a dvije vinjete situacije koje nisu uključivale vršnjačko nasilje) procjenjivali primjerenost agresivnih, pasivnih i asertivnih reakcija na skali od tri stupnja ( $d a$, ne, možda). Raspon rezultata kretao se od 0 do 48 , pri čemu je viši rezultat upućivao na bolje znanje o tome koje su reakcije primjerene u situaciji vršnjačkog nasilja. Pouzdanost je skale .67.

\section{Postupak}

U okviru projekta eConfidence (Confidence in behaviour changes through serious games - H2020) upućen je javni poziv školama za sudjelovanje u projektu. U projektu je sudjelovalo deset škola koje su odabrane između škola koje su se odazvale na poziv za sudjelovanje. Podaci koji su prezentirani u ovom istraživanju odnose se na podatke prikupljene u inicijalnom ispitivanju. Podaci su prikupljeni tijekom studenog i prosinca 2017. te siječnja 2018. godine.

Koordinatori istraživanja u školi dobili su upute o načinu regrutiranja ispitanika (metodom slučajnih brojeva odabrano je po 36 učenika iz skupine učenika od 12 do 14 godina). Učenici i njihovi roditelji informirani su o istraživanju i zamoljeni za sudjelovanje. U ispitivanju su sudjelovali učenici koji su sami, kao i njihovi roditelji, dali informirani pristanak za sudjelovanje. Učenici su upitnike na engleskom ili španjolskom jeziku ispunjavali u školi, online, putem platforme Xtend. Primjenu upitnika s prvom grupom učenika u svakoj školi provele su autorice uz prisutnost školskog koordinatora istraživanja, a s preostalim učenicima upitnik je proveo koordinator istraživanja. Ispunjavanje upitnika trajalo je do 45 minuta.

\section{Rezultati}

Za potrebe ovog istraživanja usmjerili smo se samo na dvije skupine promatrača s obzirom na njihove uobičajene reakcije u situacijama u kojima vide ili čuju da je netko od njihovih vršnjaka žrtva nasilja: one koji izvještavaju da u situacijama vršnjačkog nasilja nastoje pomoći žrtvi $(N=160)$ i one koje u situacijama vršnjačkog nasilja ne čine ništa, ali smatraju da bi trebali pomoći žrtvi $(N=66)$.

Deskriptivni podaci za sve varijable kao i njihove međusobne korelacije prikazane su u Tablici 1. 
Tablica 1.

Deskriptivni podaci i korelacije između promatranih varijabli te koeficijenti pouzdanosti primijenjenih skala

\begin{tabular}{lccccc}
\hline & Empatija & $\begin{array}{c}\text { Socijalne } \\
\text { vještine }\end{array}$ & $\begin{array}{c}\text { Primjerenost } \\
\text { reakcija }\end{array}$ & $\begin{array}{c}\text { Samodjelo- } \\
\text { tvornost }\end{array}$ & $\begin{array}{c}\text { Subjektivne } \\
\text { norme }\end{array}$ \\
\hline Socijalne vještine & $.66^{* *}$ & - & - & - & - \\
Primjerenost reakcija & $.18^{* *}$ & .10 & - & - & - \\
Samodjelotvornost & $.38^{* *}$ & $.33^{* *}$ & $.25^{* *}$ & - & - \\
Subjektivne norme & $.44^{* *}$ & $.21^{* *}$ & $.14^{*}$ & $.50^{* *}$ & - \\
Pomaganje žrtvi & $.16^{*}$ & $.18^{* *}$ & $.27^{* *}$ & $.36^{* *}$ & $.25^{* *}$ \\
\hline$M$ & 25.34 & 33.86 & 41.66 & 10.42 & 11.09 \\
\hline$S D$ & 3.91 & 5.09 & 3.78 & 2.55 & 2.18 \\
\hline Dobiveni raspon & $6-30$ & $8-40$ & $31-48$ & $3-15$ & $4-15$ \\
\hline$d$ & $1.75^{* *}$ & $1.71^{* *}$ & $2.33^{* *}$ & $1.59^{*}$ & $1.81^{* *}$ \\
\hline Indeks asimetrije & -1.20 & -1.53 & -.90 & -.10 & -.39 \\
\hline Indeks spljoštenosti & 2.63 & 4.80 & .35 & -.34 & .29 \\
\hline Cronbach a & .79 & .82 & .67 & .79 & .63 \\
\hline
\end{tabular}

$d=$ Kolmogorov-Smirnov test; ${ }^{*} p<.05 ;{ }^{* *} p<.01$.

Iz prethodne se tablice može vidjeti da distribucija rezultata na primijenjenim skalama značajno odstupa od normalne. Također je vidljivo da su promatrane varijable međusobno značajno pozitivno povezane, osim varijabli socijalne vještine i primjerenosti reakcije.

Kako bi ispitali ulogu promatranih varijabli u objašnjenju ponašanja pomaganja žrtvi kao dihotomne varijable, provedena je hijerarhijska logistička regresijska analiza. U prvom su koraku kao prediktori uvedene opće osobine učenika: socijalne vještine te empatija; u drugom je koraku uvedena varijabla poznavanja primjerenosti reakcija u situacijama vršnjačkog nasilja, a u posljednjem samodjelotvornost i subjektivne norme povezane uz pomaganje žrtvi. Kriterijska se varijabla pomaganje žrtvi odnosi na samoprocijenjeno ponašanje u situaciji svjedočenja vršnjačkog nasilja: ne činim ništa, ali mislim da bih trebao (0) ili pokušavam pomoći žrtvi (1). Rezultati su prikazani u Tablici 2.

Rezultati analize pokazuju da je model u kojem su unesene sve prediktorske varijable značajan $\left(\chi^{2}=18.96, d f=5, p<.001\right)$ i objašnjava između $18 \%$ i $25 \%$ varijance pomaganja žrtvi, dok se u posljednjem koraku vjerojatnost točne klasifikacije povećala s početnih $70.8 \%$ na $74.8 \%$. U posljednjem je koraku uspješno predviđeno $92 \%$ pomaganja žrtvi te $33.3 \%$ ne pomaganja.

Prepoznavanje primjerenosti reakcija u situacijama vršnjačkog nasilja (primjerenost asertivnih, neprimjerenost pasivnih i agresivnih reakcija) te samodjelotvornost u zaštiti žrtve značajni su pozitivni prediktori pomagačkog ponašanja. Socijalne vještine koje su se u drugom koraku pokazale kao značajan pozitivan prediktor pomaganja žrtvi u posljednjem koraku to više nisu bile. 
Martinac Dorčić, T., Smojver-Ažić, S., Rončević Zubković, B., Kolić-Vehovec, S.:

Pomaganje žrtvi vršnjačkog nasilja

Tablica 2.

Rezultati hijerarhijske logističke regresijske analize: Prediktori pomaganja žrtvi

\begin{tabular}{|c|c|c|c|c|c|c|c|c|}
\hline \multirow{2}{*}{\multicolumn{2}{|c|}{ PREDIKTORI }} & \multicolumn{7}{|c|}{ POMAGANJE ŽRTVI } \\
\hline & & $B$ & $S E B$ & $e^{B}$ & $\chi^{2}$ & $d f$ & CS. $R^{2}$ & N. $R^{2}$ \\
\hline \multirow{2}{*}{$\begin{array}{l}\vec{y} \\
\vec{\pi} \\
\overrightarrow{0} \\
\vec{d}\end{array}$} & Empatija & -.03 & .05 & 1.03 & \multirow[t]{2}{*}{$9.96^{*}$} & \multirow[t]{2}{*}{2} & \multirow[t]{2}{*}{.04} & \multirow[t]{2}{*}{.06} \\
\hline & Socijalne vještine & .07 & .04 & 1.07 & & & & \\
\hline \multirow{3}{*}{ 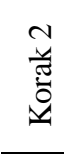 } & Empatija & .00 & .05 & 1.00 & \multirow[b]{3}{*}{$14.77^{* *}$} & \multirow[b]{3}{*}{3} & \multirow[b]{3}{*}{.10} & \multirow[b]{3}{*}{.15} \\
\hline & Socijalne vještine & $.08^{*}$ & .04 & 1.08 & & & & \\
\hline & $\begin{array}{l}\text { Primjerenost reakcija u } \\
\text { situacijama vršnjačkog nasilja }\end{array}$ & $.15^{*}$ & .04 & 1.17 & & & & \\
\hline \multirow{5}{*}{ 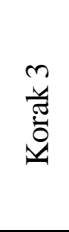 } & Empatija & -.08 & .06 & .92 & \multirow{5}{*}{$18.96^{* *}$} & \multirow{5}{*}{5} & \multirow{5}{*}{.18} & \multirow{5}{*}{.25} \\
\hline & Socijalne vještine & .08 & .04 & 1.09 & & & & \\
\hline & $\begin{array}{l}\text { Primjerenost reakcija u } \\
\text { situacijama vršnjačkog nasilja }\end{array}$ & $.14^{*}$ & .04 & 1.14 & & & & \\
\hline & Samodjelotvornost & $.27^{*}$ & .08 & 1.31 & & & & \\
\hline & Subjektivne norme & .10 & .09 & 1.11 & & & & \\
\hline
\end{tabular}

CS. $R^{2}-$ Cox i Snell $R^{2} ; N . R^{2}-$ Nagelkerke $R^{2} ;{ }^{*} p<.01 ;{ }^{* *} p<.001$.

\section{Rasprava}

Kako bi moglo ojačati vršnjake da pruže pomoć žrtvi, potrebno je identificirati čimbenike koji objašnjavaju ponašanje pomaganja žrtvi i onda pokušati na njih djelovati. Upravo je stoga cilj ovog rada bio ispitati u kojoj mjeri empatija i socijalne vještine, prepoznavanje primjerenih reakcija u situacijama vršnjačkog nasilja te samodjelotvornost i subjektivne norme vezane uz zaštitu žrtve mogu predvidjeti ponašanje pomaganja žrtvi u razdoblju rane adolescencije.

Pomaganje žrtvi u ovom se istraživanju odnosi na samoprocijenjeno ponašanje u situaciji svjedočenja vršnjačkom nasilju u dvije kategorije, koje obje podrazumijevaju osjećaj odgovornosti za dobrobit drugih kao važnog obilježja prosocijalnog ponašanja (Schroeder i sur., 1995): ne činim ništa, ali mislim da bih trebao te pokušavam pomoći žrtvi. Zanimljivo je napomenuti da većina učenika $(56 \%)$ koji su sudjelovali u istraživanju izjavljuje da pokušavaju pomoći žrtvi, što je sukladno s podacima koje navode Rigby i Johnson (2006) kada se radi o samoprocjenama vezanim uz pomaganje žrtvi. Međutim, vršnjačke procjene za pomaganje upućuju na znatno manji broj djece koja zaista pomažu (Salmivalli, Huttunen i Lagerspetz, 1997).

Među promatranim varijablama za koje smo očekivali da mogu pridonijeti predviđanju pomaganja žrtvi u posljednjem koraku logističke regresijske analize izdvojila se značajna uloga samo dviju varijabli: uloga znanja o primjerenosti reakcija i uloga samodjelotvornosti. Empatija, socijalne vještine i subjektivne norme 
nisu se pokazale kao značajni prediktori. Učenici koji izjavljuju da pokušavaju pomoći oni su koji znaju kako adekvatno postupiti u situaciji vršnjačkog nasilja te istovremeno imaju uvjerenje o tome da sami mogu biti efikasni u tom pomaganju, što je sukladno Bandurinoj teoriji samoefikasnosti (1997).

Zanimljivo je istaknuti kako su učenici općenito imali relativno visoke rezultate na korištenoj mjeri znanja o primjerenosti reakcija. Mjera korištena u ovom istraživanju predstavlja vid problemskih zadataka u kojima su prikazane situacije koje su bliske svakodnevnom iskustvu učenika koji svjedoči vršnjačkom nasilju. Viši rezultat označava poznavanja prikladnih reakcija, koje podrazumijevaju asertivno ponašanje, a izbjegavanje pasivnih i agresivnih ponašanja. Asertivnim se ponašanjem pojedinac zauzima za svoja prava i izražava misli, osjećaje i uvjerenja na izravan, pošten i prikladan način ne ugrožavajući prava drugih. Asertivni promatrači mogu igrati važnu ulogu kada svjedoče vršnjačkom nasilju jer se na odgovarajući način suprotstavljaju počinitelju nasilja i istovremeno štite žrtvu (Salmivalli i sur., 1996).

Podatak da znanje pridonosi predviđanju pomaganja žrtvi jasno pokazuje važnost informiranja učenika o poželjnim ponašanjima u situacijama vršnjačkog nasilja. Učenici mogu znati da vršnjačko nasilje nije prihvatljivo, ali ne moraju nužno znati što je prikladno ponašanje, pa su intervencije u tom smjeru potencijalno korisne u prevenciji vršnjačkog nasilja.

Osjećaj samodjelotvornosti također je važna odrednica pomaganja žrtvi. Naime, pomaganje je vršnjaku u nevolji, poput situacije vršnjačkog nasilja, rizičan pothvat, pa ako pojedinac nema uvjerenje u sposobnost da će uspješno intervenirati $u$ određenoj situaciji, manje je vjerojatno da će pokušati nešto učiniti. Naši su rezultati $\mathrm{u}$ skladu s nalazima u literaturi jer su već prijašnja istraživanja pokazala da je samodjelotvornost pomagača pozitivno povezana $\mathrm{s}$ pomagačkim ponašanjem (Barchia i Bussey, 2011; Pöyhönen i sur., 2012; Thornberg i Jungert, 2013) odnosno negativno s neuključivanjem (Gini, Albiero, Benelli i Altoe, 2008), a neki autori govore i o nekim specifičnostima vezanim uz spol. Tako npr. Cappadocia, Pepler, Cummings i Craig (2012) navode da je samodjelotvornost bila važan prediktor intervencije kod djevojčica, ali ne i kod dječaka. Samodjelotvornost može biti upravo onaj odlučujući faktor koji čini razliku između pomaganja i nepomaganja. Tako Thornberg i Jungert (2013) navode da se ponašanje pomaganja žrtvi ne može u dovoljnoj mjeri objasniti u terminima viših razina moralne osjetljivosti i niže razine moralnog neuključivanja - iako adolescenti mogu vidjeti da je određeno ponašanje, u ovom slučaju vršnjačko nasilje, neprikladno ponašanje, oni mogu ostati pasivni jer ne vjeruju da su sposobni efikasno intervenirati.

Empatija se nije pokazala značajnim prediktorom pomaganja žrtvi kada su uključeni drugi prediktori unatoč značajnoj, iako niskoj, pozitivnoj povezanosti s kriterijem. Dosadašnji su rezultati o povezanosti empatije i pomaganja žrtvi nekonzistentni i ovise o tome radi li se o afektivnoj ili kognitivnoj empatiji, ali i spolu i dobi djece (Belacchi i Farina, 2012; Caravita i sur., 2009; Van Noorden i sur., 2015). 
Čini se kao da ipak više nalaza govori u prilog pozitivnoj povezanosti afektivne empatije i reagiranja promatrača pomaganjem (npr. Belacchi i Farina, 2012; Gini i sur., 2007). Mjera empatije koja je korištena u ovom istraživanju zahvaća afektivni aspekt empatije, ali je sama kriterijska varijabla specifična. Naime, radi se o razlikovanju djece koja pomažu i djece koja ne pomažu, ali misle da bi trebali, čime se ova posljednja skupina djece možda ipak razlikuje od običnih "nepomagača". Moguće je da učenici koji pomažu žrtvi i učenici koji ne pomažu, a misle da bi trebali, zapravo podjednako doživljavaju emocije koje su usklađene sa situacijom u kojoj se nalazi određena osoba te da pomaganje, odnosno ne pomaganje ovisi o drugim faktorima, a ne sposobnosti dijeljenja emocionalnog stanja druge osobe.

Socijalne vještine, iako pozitivno povezane s kriterijskom varijablom, nisu se u zadnjem koraku analize izdvojile kao značajan prediktor, a što se s obzirom na rezultate prijašnjih istraživanja moglo očekivati. Naime, kod pomagača žrtvama nasilja karakteristična je razvijenost socijalnih vještina usmjerenih na druge (npr. pomaganje, preuzimanje odgovornosti za druge) zbog čega djeluju prosocijalno i kooperativno (Perren i sur., 2012). Mogući je razlog ovakvih rezultata upravo prije spomenuta specifičnost definiranja pomažućeg ponašanja u ovom istraživanju. Socijalne vještine jesu važne, ali sukladno rezultatima ovog istraživanja još su važnija specifična znanja o primjerenim ponašanjima zaštite žrtava vršnjačkog nasilja i uvjerenost da sami mogu primijeniti ta ponašanja.

Rezultati istraživanja ne upućuju na značaj subjektivnih normi u predviđanju pomaganja žrtvi unatoč njihovoj međusobnoj pozitivnoj povezanosti. Čini se da pojedinci koji pokušavaju pomoći kao i oni koje ne pomažu, ali misle da bi trebali, u podjednakoj mjeri vjeruju da je pomaganje žrtvi očekivano i poželjno ponašanje. Međutim, unatoč namjeri da pomognu žrtvi, promatrači mogu situaciju vršnjačkog nasilja procijeniti prerizičnom da bi se upustili u pomaganje (Pozzoli i Gini, 2013).

U interpretaciji rezultata ovog istraživanja važno je u obzir uzeti i njegova ograničenja. Jedno je od njih činjenica da se analizirani podaci temelje na samoprocjenama i upitno je u kojoj mjeri djeca imaju dobar uvid u vlastito funkcioniranje. Mjere stvarnog ponašanja u konkretnim situacijama vršnjačkog nasilja svakako bi bile korisne (npr. procjene vršnjaka). Osim toga, mjera znanja o primjerenost reakcija u situaciji vršnjačkog nasilja konstruirana je za potrebe ovog istraživanja i nije validirana izvan konteksta ovog projekta. Nadalje, iako je uzorak djece bio slučajan i iako su djeca dolazila iz različitih zemalja i različitog sociokulturalnog miljea, sva su pohađala škole koje su se prijavile za sudjelovanje u projektu, što može odražavati njihovu veću svjesnost i osjetljivost za teme vršnjačkog nasilja u školskom okruženju. Buduća bi istraživanja trebala koristiti različite mjere ponašanja u situacijama vršnjačkog nasilja, kao i druge relevantne varijable, $\mathrm{s}$ obzirom na ovdje dobiven postotak objašnjene varijance pomagačkog ponašanja, poput percepcije rizika za intervenciju te ostale varijable u okviru teorije planiranog ponašanja, kao i voditi računa o reprezentativnosti uzorka te mogućim spolnim razlikama. 
Jačanje vršnjaka - promatrača za pružanje aktivne podrške i pomaganje žrtvi ključ je efikasnih intervencija usmjerenih prema suzbijanju vršnjačkog nasilja koje trebaju biti prikladne njihovoj razvojnoj dobi (npr. Frey, Hirschstein, Edström i Snell, 2009; Pepler, Craig i O'Connell, 2010; Salmivalli, Kärnä i Poskiparta, 2010). Rezultati ovog istraživanja upućuju na to kako je u cilju osnaživanja učenika za pomaganje važno informirati ih o tome kako reagirati u situacijama vršnjačkog nasilja i jačati njihov osjećaj samodjelotvornosti. Usmjerenost upravo na razdoblje rane adolescencije višestruko je opravdana. U ovom je periodu vršnjačko nasilje najučestalije (Olweus, 1998; Velki i Kuterovac-Jagodić, 2014), a usmjerenost na vršnjake popraćena je pritiskom za održavanjem socijalnog statusa (Espelage i Holt, 2001). Adolescenti postaju osjetljiviji na socijalne signale iz okoline o kojima ovisi njihova motivacija za određena ponašanja (Blakemore i Mills, 2014). Premda djeca smatraju da je vršnjačko nasilje neprikladan obrazac interakcije (Salmivalli i Voeten, 2004), još uvijek im može nedostajati konkretnih znanja o tome kako se ponašati kad se zateknu u takvoj situaciji. Kako je adolescencija razdoblje učenja i mogućnosti, prepoznavanje odrednica ponašanja u situaciji vršnjačkog nasilja bitno je za kreiranje dobno prikladnih preventivnih programa (Yeager, 2017). Razvijene su brojne intervencije koje su imale za cilj prevenirati ili smanjiti vršnjačko nasilje, a u Hrvatskoj se u školama već niz godina provode preventivni programi (Velki i Ozdanovac, 2014). Jedan od njih je program "Za sigurno i poticajno okruženje u školama" kao dio projekta "Stop nasilju među djecom" u organizaciji UNICEF-a (2010). Drugi je nastao u okviru projekta "Prevencija zlostavljanja djece kroz školski sustav i lokalnu zajednicu" (CAP - Child Assault Prevention; Udruga roditelja KORAK PO KORAK, 2010). Među različitim pristupima intervencije kao pogodan su se medij pokazale i informacijsko-komunikacijske tehnologije. Tako je primjerice razvijena igra "Fear not" (Vannini i sur., 2011), koja je usmjerena na žrtve s ciljem da one povećaju svoje vještine suočavanja te na promatrače, kod kojih je cilj bio povećati empatiju i pomagačko ponašanje. I ovo je istraživanje provedeno u okviru projekta eConfidence (Confidence in behaviour changes through serious games H2020), kojem je jedan od ciljeva bio konstruirati ozbiljnu računalnu igru usmjerenu na poticanje ponašanja pomaganja u situaciji vršnjačkog nasilja. Koristeći konceptualni okvir teorije planiranog ponašanja očekuje se da će se igranje igrice odraziti na promjenu u znanju, stavovima, subjektivnim normama i percipiranoj ponašajnoj kontroli te tako povećati broj onih koji pomažu u situaciji svjedočenja vršnjačkom nasilju.

Zaključno, rezultati ovog istraživanja potvrđuju važnost informiranja učenika o prepoznavanju i osvještavanju primjerenih reakcija promatrača u situacijama vršnjačkog nasilja te jačanja samodjelotvornosti s ciljem povećanja vjerojatnosti pomaganja žrtvi. 


\section{Literatura}

Ajzen, I. (1991). The theory of planned behaviour. Organizational Behaviour and Human Decision Processes, 50, 179-211.

Ajzen, I. (2002). Construction of a standard questionnaire for the theory of planned behaviour. Preuzeto s https://people.umass.edu/aizen/pdf/tpb.measurement.pdf

Alajbeg, A., Dragoslavić, M. i Davidović, N. V. (2018). Doprinos socijalne samoefikasnosti i nekih sociodemografskih čimbenika u objašnjenju različitih uloga djece u vršnjačkom nasilju. Hrvatska revija za rehabilitacijska istraživanja, 54(1), 10-23.

Bandura, A. (1997). Self-efficacy: The exercise of control. New York: Freeman.

Bandura, A. (2001). Social cognitive theory: An agentic perspective. Annual Review of Psychology, 52, 1-26.

Barchia, K. i Bussey, K. (2011). Predictors of student defenders of peer aggression victims: Empathy and social cognitive factors. International Journal of Behavioral Development, 35(4), 289-297.

Belacchi, C. i Farina, E. (2012). Feeling and thinking of others: Affective and cognitive empathy and emotion comprehension in prosocial/hostile preschoolers. Aggressive Behavior, 38(2), 150-165.

Blakemore, S. J. i Mills, K. L. (2014). Is adolescence a sensitive period for sociocultural processing?. Annual Review of Psychology, 65, 187-207.

Bloom, P. (2017). Empathy and its discontents. Trends in Cognitive Sciences, 21(1), 24-31.

Boulton, M. J., Bucci, E. i Hawker, D. D. (1999). Swedish and English secondary school pupils' attitudes towards, and conceptions of, bullying: Concurrent links with bully/victim involvement. Scandinavian Journal of Psychology, 40(4), 277-284.

Bryant, B. K. (1982). An index of empathy for children and adolescents. Child Development, $53,413-425$.

Buljan Flander, G., Durman Marijanović, Z. i Ćorić Špoljar, R. (2007). Pojava nasilja među djecom s obzirom na spol, dob i prihvaćenost/odbačenost u školi. Društvena istraživanja, 16(1-2), 157-174.

Cappadocia, M. C., Pepler, D., Cummings, J. G. i Craig, W. (2012). Individual motivations and characteristics associated with bystander intervention during bullying episodes among children and youth. Canadian Journal of School Psychology, 27(3), 201-216.

Caravita, S. C., Di Blasio, P. i Salmivalli, C. (2009). Unique and interactive effects of empathy and social status on involvement in bullying. Social Development, 18(1), 140-163.

Coloroso, B. (2005). A bully's bystanders are never innocent. The Education Digest, 70(8), 49-51.

Costley, J. H. M., Sueng-Lock, H. i Ji-Eun, L. (2013). Preservice teachers' response to bullying vignettes: The effect of bullying type and gender. International Journal of Secondary Education, 1(6), 45-52. 
Davis, M. H. (1983). The effects of dispositional empathy on emotional reactions and helping: A multidimensional approach. Journal of Personality, 51(2), 167-184.

Espelage, D., Green, H. i Polanin, J. (2012). Willingness to intervene in bullying episodes among middle school students: Individual and peer-group influences. The Journal of Early Adolescence, 32(6), 776-801.

Espelage, D. L. i Holt, M. K. (2001). Bullying and victimization during early adolescence: Peer influences and psychosocial correlates. Journal of Emotional Abuse, 2(2-3), 123 142.

Frey, K. S., Hirschstein, M. K., Edstrom, L. V. i Snell, J. L. (2009). Observed reductions in school bullying, nonbullying aggression, and destructive bystander behavior: A longitudinal evaluation. Journal of Educational Psychology, 101(2), 466.

Gini, G., Albiero, P., Benelli, B. i Altoè, G. (2007). Does empathy predict adolescents' bullying and defending behavior? Aggressive Behavior: Official Journal of the International Society for Research on Aggression, 33(5), 467-476.

Gini, G., Albiero, P., Benelli, B. i Altoe, G. (2008). Determinants of adolescents' active defending and passive bystanding behavior in bullying. Journal of Adolescence, 31(1), 93-105.

Gini, G., Pozzoli, T., Borghi, F. i Franzoni, L. (2008). The role of bystanders in students' perception of bullying and sense of safety. Journal of School Psychology, 46(6), 617638.

Glew, G. M., Fan, M. Y., Katon, W., Rivara, F. P. i Kernic, M. A. (2005). Bullying, psychosocial adjustment, and academic performance in elementary school. Archives of Pediatrics \& Adolescent Medicine, 159(11), 1026-1031.

Heirman, W. i Walrave, M. (2012). Predicting adolescent perpetration in cyberbullying: An application of the theory of planned behaviour. Psicothema, 24, 614-620.

Hymel, S., Schonert-Reichl, K. A., Bonanno, R. A., Vaillancourt, T. i Henderson, N. R. (2010). Bullying and morality: Understanding how good kids can behave badly. U: S. R. Jimerson, S. M. Swearer i D. Espelage (Ur.), The handbook of school bullying: An Iinternational perspective (str. 101-118). New York: Routledge.

Jolliffe, D. i Farrington, D. P. (2006). Examining the relationship between low empathy and bullying. Aggressive Behavior: Official Journal of the International Society for Research on Aggression, 32(6), 540-550.

Jordan, M. R., Amir, D. i Bloom, P. (2016). Are empathy and concern psychologically distinct?. Emotion, 16(8), 1107-1116.

Latané, B. i Darley, J. (1969). Bystander "apathy". American Scientist, 57, 244-268.

Lovett, B. J. i Sheffield, R. A. (2007). Affective empathy deficits in aggressive children and adolescents: A critical review. Clinical Psychology Review, 27(1), 1-13.

Matson, J. L., Rotatori, A. F. i Helsel, W. J. (1983). Development of a rating scale to measure social skills in children: The Matson Evaluation of Social Skills with Youngsters (MESSY). Behaviour Research and Therapy, 21(4), 335-340. 
Matson, J. L., Neal, D., Fodstad, J. C., Hess, J. A., Mahan, S. i Rivet, T. T. (2010). Reliability and validity of the Matson Evaluation of Social Skills with Youngsters. Behavior Modification, 34(6), 539-558.

Miller, P. A. i Eisenberg, N. (1988). The relation of empathy to aggressive and externalizing/antisocial behavior. Psychological Bulletin, 103(3), 324-344.

Nesdale, D., Griffith, J., Durkin, K. i Maass, A. (2005). Empathy, group norms and children's ethnic attitudes. Journal of Applied Developmental Psychology, 26(6), 623-637.

Oh, I. i Hazler, R. J. (2009). Contributions of personal and situational factors to bystanders' reactions to school bullying. School Psychology International, 30(3), 291-310.

Olweus, D. (1993). Victimization by peers: Antecedents and long-term outcomes. U: K. H. Rubin i A. Asendorpf (Ur.), Social withdrawal, inhibition, and shyness in childhood (str. 315-341). Hillsdale, NJ: Erlbaum.

Olweus, D. (1996). The Revised Olweus Bully/Victim Questionnaire. Bergen, Norway: Research Center for Health Promotion, University of Bergen.

Olweus, D. (1998). Nasilje među djecom u školi: Što znamo i što možemo učiniti. Zagreb: Školska knjiga.

Padgett, S. i Notar, C. E. (2013). Bystanders are the key to stopping bullying. Universal Journal of Educational Research, 1(2), 33-41.

Pepler, D., Craig, W. i O'Connell, P. (2010). Peer processes in bullying: Informing prevention and intervention strategies. U: S. R. Jimerson, S. M. Swearer i D. L. Espelage (Ur.), Handbook of bullying in schools: An international perspective (str. 469-479). New York: Routledge.

Perren, S. i Alsaker, F. D. (2006). Social behavior and peer relationships of victims, bullyvictims, and bullies in kindergarten. Journal of Child Psychology and Psychiatry, 47, 45-57.

Perren, S., Forrester-Knauss, C. i Alsaker, F. D. (2012). Self-and other-oriented social skills: Differential associations with children's mental health and bullying roles. Journal for Educational Research Online/Journal für Bildungsforschung Online, 4(1), 99-123.

Pöyhönen, V., Juvonen, J. i Salmivalli, C. (2010). What does it take to stand up for the victim of bullying? The interplay between personal and social factors. Merrill-Palmer Quarterly, 56, 143-163.

Pöyhönen, V., Juvonen, J. i Salmivalli, C. (2012). Standing up for the victim, siding with the bully or standing by? Bystander responses in bullying situations. Social Development, 21(4), 722-741.

Pozzoli, T. i Gini, G. (2013). Why do bystanders of bullying help or not? A multidimensional model. The Journal of Early Adolescence, 33(3), 315-340.

Rajhvan Bulat, L. i Ajduković, M. (2012). Obiteljske i psihosocijalne odrednice vršnjačkog nasilja među mladima. Psihologijske teme, 21, 167-194. 
Reić Ercegovac, I. (2016). Doživljeno vršnjačko nasilje: Relacije s dobi, spolom, razrednim ozračjem i školskim uspjehom. Školski vjesnik: Časopis za pedagogijsku teoriju $i$ praksu, 65(2), 251-271.

Reijntjes, A., Kamphuis, J. H., Prinzie, P. i Telch, M. J. (2010). Peer victimization and internalizing problems in children: A meta-analysis of longitudinal studies. Child Abuse \& Neglect, 34(4), 244-252.

Reijntjes, A., Kamphuis, J. H., Prinzie, P., Boelen, P. A., Van der Schoot, M. i Telch, M. J. (2011). Prospective linkages between peer victimization and externalizing problems in children: A meta-analysis. Aggressive Behavior, 37(3), 215-222.

Rigby, K. i Johnson, B. (2006). Expressed readiness of Australian schoolchildren to act as bystanders in support of children who are being bullied. Educational Psychology, 26(3), 425-440.

Salmivalli, C., Huttunen, A. i Lagerspetz, K. M. (1997). Peer networks and bullying in schools. Scandinavian Journal of Psychology, 38(4), 305-312.

Salmivalli, C., Karna, A. i Poskiparta, E. (2010). Development, evaluation, and diffusion of a national anti-bullying program (KiVA). U: B. Doll, W. Pfohl i J. Yoon (Ur.), Handbook of youth prevention science (str. 238-252). New York: Routledge.

Salmivalli, C., Lagerspetz, K., Björkqvist, K., Österman, K. i Kaukiainen, A. (1996). Bullying as a group process: Participant roles and their relations to social status within the group. Aggressive Behavior: Official Journal of the International Society for Research on Aggression, 22(1), 1-15.

Salmivalli, C. i Voeten, M. (2004). Connections between attitudes, group norms, and behaviour in bullying situations. International Journal of Behavioral Development, 28(3), 246-258.

Salmivalli, C., Voeten, M. i Poskiparta, E. (2011). Bystanders matter: Associations between reinforcing, defending, and the frequency of bullying behavior in classrooms. Journal of Clinical Child \& Adolescent Psychology, 40(5), 668-676.

Schroeder, D. A., Penner, L. A., Dovidio, J. F. i Piliavin, J. A. (1995). The psychology of helping and altruism: Problems and puzzles. New York: McGraw-Hill.

Singer, T. i Klimecki, O. M. (2014). Empathy and compassion. Current Biology, 24(18), 875878.

Spence, S. H. (2003). Social skills training with children and young people: Theory, evidence and practice. Child and Adolescent Mental Health, 8(2), 84-96.

Sutton, J., Smith, P. K. i Swettenham, J. (1999). Social cognition and bullying: Social inadequacy or skilled manipulation?. British Journal of Developmental Psychology, 17, 435-450.

Sušac, N., Ajduković, M. i Rimac, I. (2016). Učestalost vršnjačkog nasilja s obzirom na obilježja adolescenata i doživljeno nasilje u obitelji. Psihologijske teme, 25(2), 197-221. 
Thornberg, R. i Jungert, T. (2013). Bystander behavior in bullying situations: Basic moral sensitivity, moral disengagement and defender self-efficacy. Journal of Adolescence, $36(3), 475-483$.

Udruga roditelja KORAK PO KORAK. (2010). CAP program. Preuzeto s http://www.udrugaroditeljakpk.hr/cap-program-prevencije-zlostavljanja-djece-sp907134761/opcenito-o-cap-programu/129-cap-program

UNICEF. (2010). Za sigurno $i$ poticajno okruženje $u$ školama-priručnik. Preuzeto s https://www.unicef.hr/wp-ontent/uploads/2015/09/Stop_nasilju_medju_djecom_ prirucnik.pdf

Vannini, N., Enz, S., Sapouna, M., Wolke, D., Watson, S., Woods, S., ... Aylett, R. (2011). "FearNot!": A computer-based anti-bullying-programme designed to foster peer intervention. European Journal of Psychology of Education, 26(1), 21-44.

Van Leeuwen, E. i Täuber, S. (2011). Demonstrating knowledge: The effects of group status on outgroup helping. Journal of Experimental Social Psychology, 47(1), 147-156.

Van Noorden, T. H., Haselager, G. J., Cillessen, A. H. i Bukowski, W. M. (2015). Empathy and involvement in bullying in children and adolescents: A systematic review. Journal of Youth and Adolescence, 44(3), 637-657.

Velki, T. i Kuterovac Jagodić, G. (2014). Individualni i kontekstualni činitelji dječjega nasilničkoga ponašanja prema vršnjacima. Ljetopis socijalnog rada, 21(1), 33-64.

Velki, T. i Ozdanovac, K. (2014). Preventivni programi usmjereni na smanjenje vršnjačkog nasilja u osnovnim školama na području Osječko-baranjske županije. Školski vjesnik: Časopis za pedagogijsku teoriju i praksu, 63(3), 327-352.

Wolke, D. i Lereya, S. T. (2015). Long-term effects of bullying. Archives of Disease in Childhood, 100(9), 879-885.

Yeager, D. S. (2017). Social and emotional learning programs for adolescents. The Future of Children, 27, 73-94.

Yun, H. Y. i Graham, S. (2018). Defending victims of bullying in early adolescence: A multilevel analysis. Journal of Youth and Adolescence, 47(9), 1926-1937.

Zwierzynska, K., Wolke, D. i Lereya, T. S. (2013). Peer victimization in childhood and internalizing problems in adolescence: A prospective longitudinal study. Journal of Abnormal Child Psychology, 41(2), 309-323. 


\title{
Determinants of Helping the Victim in Situations of Peer Violence
}

\begin{abstract}
Although bystanders do not actively participate in situations of peer violence, their reactions can play an important role in protecting the victim. Therefore, this paper aims to examine to what extent social skills, recognition of appropriate reactions in peer violence situations, and self-efficacy and subjective norms related to victim protection can predict the helping behaviour. Students aged 12 to $14(M=12.69 ; S D=0.72)$ from ten European schools (from Spain, Malta, UK and Ireland) participated in the study. From the initial sample of 359 students, 226 students (54.9\% of girls) stated that were exclusively bystanders in bullying situations (and not victims and/or bullies). In this paper, we have focused on two groups of bystanders: those who report that they are trying to help victims in situations of peer violence $(70.8 \%)$ and those who do not do anything in situations of peer violence, but think that they should help the victim (29.2\%). The participants filled out an on-line questionnaire with teachers' supervision. It consisted of a series of scales, constructed or adapted for the purpose of this research: Bully/victim questionnaire, Empathy scale, Social skills scale, Selfefficacy and subjective norm for protecting the victim scale, and Questionnaire about the appropriateness of reaction in a bullying situation. Hierarchical logistic regression was conducted to check the contribution of studied variables in the prediction of helping behaviour. Results show that the examined variables explain between $18 \%$ and $25 \%$ of the variance in helping behaviour. Recognizing the appropriateness of reactions in peer violence situations (the appropriateness of the assertive, the inappropriateness of passive and aggressive reactions) and self-efficacy in victim protection are significant positive predictors of helping behaviour. The obtained results point to the importance of raising awareness of appropriate bystander reactions in situations of peer violence and enhancing self-efficacy to increase the likelihood of helping the victim.
\end{abstract}

Keywords: bullying, helping the victim, empathy, social skills, self-efficacy

Primljeno: 22.7.2019. 